\title{
High Performance LSC Infiltrated LSCF Oxygen Electrode for High Temperature Steam Electrolysis Application
}

\author{
V. Vibhu, ${ }^{1, \mathrm{z}}$ S. Yildiz, ${ }^{1}$ I. C. Vinke, ${ }^{1}$ R.-A. Eichel, ${ }^{1,2}$ J.-M. Bassat, ${ }^{3}$ and L. G. J. de Haart ${ }^{1, *}$ \\ ${ }^{I}$ Institute of Energy and Climate Research, Fundamental Electrochemistry (IEK-9), Forschungszentrum Jülich GmbH, \\ 52425 Jülich, Germany \\ ${ }^{2}$ Institute of Physical Chemistry, RWTH Aachen University, 52074 Aachen, Germany \\ ${ }^{3}$ CNRS, Université de Bordeaux, Institut de Chimie de la Matière Condensée de Bordeaux (ICMCB), F-33608 Pessac \\ Cedex, France
}

\begin{abstract}
This work is focused on $\mathrm{La}_{0.6} \mathrm{Sr}_{0.4} \mathrm{CoO}_{3-\delta}$ (LSC) infiltrated $\mathrm{La}_{0.58} \mathrm{Sr}_{0.4} \mathrm{Co}_{0.2} \mathrm{Fe}_{0.8} \mathrm{O}_{3-\delta}$ (LSCF) oxygen electrode for high temperature steam electrolysis aimed at efficient hydrogen production. In this respect, first the chemical and structural stability of both LSCF and LSC materials are investigated as a function of temperature under air and oxygen. The electrochemical performance of LSC infiltrated LSCF oxygen electrode is then investigated for steam electrolysis and compared with conventional LSCF electrode. The symmetrical half-cell as well as single cell containing LSCF oxygen electrode with and without LSC infiltration are characterized using electrochemical impedance spectroscopy in the temperature range $700-900^{\circ} \mathrm{C}$. It is observed that the symmetrical cell as well as single cells with LSC infiltrated LSCF electrode performs better than the conventional LSCF electrode. The degradation experiments were performed with the symmetrical cells under polarizations. Post-test analysis using SEM-EDX was performed to investigate the changes of electrode and electrode/electrolyte interface microstructures.
\end{abstract}

(C) 2019 The Electrochemical Society. [DOI: 10.1149/2.0741902jes]

Manuscript submitted November 20, 2018; revised manuscript received December 21, 2018. Published January 17, 2019.

Solid Oxide Electrolysis Cells (SOECs) have attracted considerable interest in the attainment of zero emission and high purity hydrogen production. ${ }^{1-3}$ Additionally, the SOECs can be used for electrolysis of $\mathrm{CO}_{2}$ and $\mathrm{H}_{2} \mathrm{O}$ to produce syngas $\left(\mathrm{H}_{2}+\mathrm{CO}\right)$ which can be further used for the production of synthetic fuels. ${ }^{4-7}$ The high temperature electrolysis (SOECs) has main advantage over the low temperature electrolysis (like alkaline electrolysis or PEM electrolysis) of its high efficiency. Moreover, the renewable energy sources like solar or wind can be combined with SOEC systems to store electrical energy as chemical energy in the form of hydrogen, methane, methanol etc. Notwithstanding these advantages, the commercialization of high temperature SOEC is still an issue. In general for the commercialization of SOECs, the system must meet the certain criteria such as low cost, modularity, easy maintenance and durability.

Recently, a lot of research focuses on the long term durability of SOECs. ${ }^{8-11}$ Several degradation phenomenon have been reported, for instance in the fuel electrode, redistribution of nickel or formation of nanoparticles of nickel; for the electrolyte, the formation of oxygen bubbles at the grain boundaries, close to oxygen electrode which leads to delamination of the oxygen electrode.

Generally during solid oxide cells (SOC) operation, the electrode polarizations induce large voltage losses especially at the oxygen electrode compared to the fuel electrode, ${ }^{12-15}$ therefore the modification in the existing material as well as investigation of new oxygen electrode materials are still required in order to enhance the oxygen electrode reaction kinetics. Moreover, the enhancement in oxygen electrode reaction kinetics will be further beneficial to increase the hydrogen production rate from water electrolysis using SOECs.

With respect to oxygen electrode, several Mixed Ionic and Electronic Conducting (MIEC) oxide materials have been comprehensively studied for solid oxide cells. ${ }^{16-28}$ Usually, oxygen electrode functions include several contributing processes: (a) transport of gases through the pores of the electrode; (b) chemical and electrochemical processes on the electrode surface associated with oxygen adsorption, dissociation and/or reduction; (c) transport of ionic and electronic defects along surfaces, across interfaces, and through the bulk; and (d) incorporation of oxygen species into the electrolyte. The elementary electrode property requirements include sufficient porosity, excellent surface catalytic activity and high electronic and sufficient ionic conductivity. ${ }^{29,30}$ Moreover, to confirm system reliability and durability through thermal cycling, ideal oxygen electrode materials

*Electrochemical Society Member.

${ }^{z}$ E-mail: v.vibhu@fz-juelich.de should have a suitable thermal expansion coefficient (TEC) and chemical compatibility with the electrolyte and the interconnect materials as well as superior stability under oxidizing atmosphere.

In this respect, cobaltite based mixed ionic and electronic conducting oxides, like ( $\mathrm{La}, \mathrm{Sr})(\mathrm{Co}, \mathrm{Fe}) \mathrm{O}_{3}$ (LSCF) have been extensively studied. Usually a Gd-doped ceria (GDC) interlayer is used between LSCF electrode and yttria stabilized zirconia (YSZ) electrolyte to avoid the formation of insulating phases like $\mathrm{La}_{2} \mathrm{Zr}_{2} \mathrm{O}_{7}$ and $\mathrm{SrZrO}_{3}$. If the GDC layer is not sufficiently dense then the high mobility of surface segregated $\mathrm{SrO}$ on the LSCF grain surface and the high chemical driving force are assumed responsible for the long range transport of $\mathrm{SrO}$ and formation of $\mathrm{SrZrO}_{3}$ occurs at the GDC/YSZ interface. The formation of Sr- and/or Co-rich particles on the surface of dense LSCF while only Sr-enrichment on the surface of aged porous LSCF electrode during short term SOEC operation is usually observed. ${ }^{31,32}$ When the cell is kept for long duration at operating conditions, then particularly the delamination of oxygen electrode at the electrode/electrolyte interface is the most common mode of failure. $^{33,34}$ Two mechanisms are possible for such kind of delamination, (a) the oxygen evolution reaction at the oxygen electrode leads to a locally high partial pressure of oxygen $\left(p \mathrm{O}_{2}\right)$ in the electrode and at the electrode/electrolyte interface forming pores and/or (b) change in stoichiometry of electrode causing pores, in SOEC mode, further leads to increase in electrode overpotential. ${ }^{33,35}$ Other possible reasons for the degradation of LSCF electrode containing cells could be the surface modification such as the formation of $\mathrm{Sr}$ - and /or Co-rich particles on the surface of LSCF electrode which further leads to decrease the oxygen electrode reaction kinetics. ${ }^{31,35,36}$ It is also possible that the formation of both La-rich region and Sr-rich regions are increased during ageing process. ${ }^{31,37}$ Moreover, the change of LSCF phase from rhombohedral to cubic is also probable under anodic polarization in the bulk of electrode, as reported by Kim et al. ${ }^{38}$

One way to avoid such difficulties could be to increase the activity of oxygen electrodes by introducing highly active catalyst materials by infiltration. ${ }^{39-41}$ Surface modification through infiltration is an effective approach to enhance electrode functionality while retaining advantageous qualities of each constituent material. There are three main advantages of surface modification of electrodes through infiltration, (a) it is an effective approach to enhance the electro-catalytic activity at low cost with high stability of electrode, (b) utilization of a wide variety of active materials that cannot be used in a conventional electrode fabrication process due to high reactivity with the other components of the SOC or high cost, (c) it allows production of nanosized and/or nano-structured electrodes thus creating higher surface areas of electro-catalytic active materials. Recently a lot of work has 
been published on the preparation of oxygen electrodes with several different MIEC materials using infiltration techniques, ${ }^{17,42-49}$ show improvement in the performance of the electrode due to enhancement of active reaction sites/electro-catalytic activity of the electrode.

In general, it can be seen that the infiltration of additives/catalyst to the electrode leads to an improvement in the cell performance, however in different extent, and their effect during long term is also dependent on the nature of catalyst. ${ }^{41,46}$ For instance Ding et al. have reported the effect of infiltration of LSM, PSM $\left(\mathrm{Pr}_{0.75} \mathrm{Sr}_{0.2} \mathrm{MnO}_{3-\delta}\right)$, PSCM $\left(\mathrm{PrSrCoMnO}_{6-\delta}\right)$ in LSCF backbones. The best performance was obtained for PSCM infiltrated LSCF electrode. ${ }^{46,50}$ More precisely the lowest $R_{p}$ is observed for PSCM electrode with the YSZ electrolyte and SDC buffer layer. Samson et al. have reported the infiltration of Co-based materials in a GDC backbone. ${ }^{17,49}$ Electrochemical characterization revealed that the lowest polarization resistance $\left(R_{\mathrm{p}}\right)$ value at $600^{\circ} \mathrm{C}$ is obtained for $\mathrm{La}_{0.6} \mathrm{Sr}_{0.4} \mathrm{Co}_{1.05} \mathrm{O}_{3-\delta}(\mathrm{LSC})\left(62 \mathrm{~m} \Omega . \mathrm{cm}^{2}\right)$, then for $\mathrm{LaCoO}_{3}\left(79 \mathrm{~m} \Omega . \mathrm{cm}^{2}\right)$ and highest (more than three times of LSC) for $\mathrm{Co}_{3} \mathrm{O}_{4}$ infiltrated electrodes $\left(270 \mathrm{~m} \Omega . \mathrm{cm}^{2}\right)$. This could be related to the both ionic and electronic conductivities of the materials. The electronic conductivity of LSC is highest among all these materials, following the order LSC $\left(2000 \mathrm{~S} . \mathrm{cm}^{-1}\right)>\mathrm{LaCoO}_{3}\left(600 \mathrm{~S} . \mathrm{cm}^{-1}\right)>$ $\mathrm{Co}_{3} \mathrm{O}_{4}\left(2{\left.\mathrm{~S} . \mathrm{cm}^{-1}\right)}\right)$ at $600-800^{\circ} \mathrm{C} .{ }^{51-53}$ Moreover, LSC has significantly high value of ionic conductivity $\left(0.01-0.45{\mathrm{~S} . \mathrm{cm}^{-1}}^{-}\right)$in addition to high electronic conductivity at the operating temperature range 650 $1000^{\circ} \mathrm{C},{ }^{54}$ leading to a very promising electrode material. It means that the activity of the catalyst is somehow important for the electrochemical performance of the cell. Bidrawn et al. have reported the effect of different additives in the LSF-YSZ and LSM-YSZ cathodes and found that the improvement in the performance of the cell is more associated with the electrode structure. ${ }^{55}$ In addition, the electrode performance strongly depends on the surface area of the infiltrated catalyst. ${ }^{56}$ All these results clearly indicate that the improvement through infiltration could be associated with the electro-catalytic properties as well as the structure of the infiltrated electrode.

In this work we have focused our work to stabilize the LSCF oxygen electrode under anodic polarizations by performing LSC infiltration in LSCF electrode. As in the SOEC mode the oxygen evolution reaction takes place at oxygen electrode, therefore the stability of the oxygen electrode in oxidizing atmosphere is very important. In this study we have compared the stability of both LSCF and LSC oxygen electrodes in air and oxygen atmosphere using high temperature in-situ XRD experiments. Further, we studied the influence of LSC infiltration in LSCF electrode on both performance and degradation during operation, by both symmetrical as well as single cells comprising conventional LSCF and LSC infiltrated LSCF electrodes.

\section{Experimental}

Powder preparation.-Both $\mathrm{La}_{0.58} \mathrm{Sr}_{0.4} \mathrm{Co}_{0.2} \mathrm{Fe}_{0.8} \mathrm{O}_{3-\delta}$ (LSCF) and $\mathrm{La}_{0.6} \mathrm{Sr}_{0.4} \mathrm{CoO}_{3-\delta}$ (LSC) powders were synthesized by a standard solid state route. $\mathrm{La}_{2} \mathrm{O}_{3}\left(99.99 \%\right.$, Sigma Aldrich), $\mathrm{SrCO}_{3}$ (99.9\%, Sigma Aldrich), $\mathrm{Fe}_{2} \mathrm{O}_{3}$ (99\%, Sigma Aldrich) and $\mathrm{Co}_{3} \mathrm{O}_{4}(99 \%$, Alfa Aeser) powders were used as precursors. $\mathrm{La}_{2} \mathrm{O}_{3}$ was initially heat-treated at $900^{\circ} \mathrm{C}$ overnight to remove residual water before weighing. The powders were weighed according to the compositions and then ball-milled for $4 \mathrm{~h}$ at $250 \mathrm{rpm}$ using zirconia balls and isopropanol (98.8\%, VWR). After drying at $80^{\circ} \mathrm{C}$ overnight, the mixtures were then calcined in air at $1080^{\circ} \mathrm{C}$ for $8 \mathrm{~h}$. After getting the pure phase, the powders were again ball-milled for $4 \mathrm{~h}$ in order to get the average particle size $\sim 1 \mu \mathrm{m}$.

$X$-ray diffraction analysis.-The powders were first investigated by X-Ray diffraction (XRD) at room temperature using a PANanalytical X'pert MPD diffractometer with $\mathrm{Cu}-\mathrm{K}_{\alpha}$ incident radiation to check the purity of phase. The XRD vs. T (i.e. in situ XRD) were then performed to check the stability of phase with temperature under air and oxygen atmosphere. The data were recorded for both heating and cooling, from room temperature up to $1000^{\circ} \mathrm{C}$, by steps of $100^{\circ} \mathrm{C}$. The heating and cooling rate was fixed to $2^{\circ} \mathrm{C} \cdot \mathrm{min}^{-1}$, the powder being thermally equilibrated for $2 \mathrm{~h}$ at each particular temperature prior to the XRD data recording. The X-ray diffractogram recorded on the powder during cooling is preferentially reported here thanks to a thermal equilibrium which is expected to be more easily reached in this case.

Each X-ray diffractogram was fitted by profile matching using the Fullprof software.

Cells preparation.-Symmetrical half-cells (electrode//GDC//8YSZ//GDC//electrode) were prepared using dense sheets of 8 YSZ ( 8 mol.\% yttria stabilized zirconia from, Kerafol) with diameter $\approx 20 \mathrm{~mm}$ and thickness $\approx 250 \mu \mathrm{m}$. Terpineol-based slurries were prepared for LSCF and GDC powder. In order to increase the chemical stability of the half-cells, a 3-4 $\mu \mathrm{m}$ GDC layer was initially screen printed on both sides of the 8YSZ electrolyte sheets and sintered at $1350^{\circ} \mathrm{C}$ for $1 \mathrm{~h}$ under air. The LSCF layer (thickness $\approx 40 \mu \mathrm{m}$, area $\approx 1 \mathrm{~cm}^{2}$ ) was then screen printed on each side. The optimal sintering temperature of the electrode in air was previously determined in our group was $1080^{\circ} \mathrm{C}$ for $3 \mathrm{~h}$.

For single cell measurements, commercial electrode supported half-cells (CeramTec, ASC-10C type) made of a $400 \mu \mathrm{m}$ thick Ni$8 Y S Z$ cathode $(\varnothing=20 \mathrm{~mm})$, a $10 \mu \mathrm{m}$ thick $8 Y S Z$ electrolyte membrane $(\varnothing=20 \mathrm{~mm})$, a $3-4 \mu \mathrm{m}$ thick GDC layer $(\varnothing=20 \mathrm{~mm})$ and a $40 \mu \mathrm{m}$ thick LSCF electrode $(\varnothing=10 \mathrm{~mm})$ were used.

The LSC infiltration solution $(0.05 \mathrm{M})$ was prepared by dissolving $\mathrm{La}\left(\mathrm{NO}_{3}\right)_{3} \cdot 6 \mathrm{H}_{2} \mathrm{O}, \mathrm{Sr}\left(\mathrm{NO}_{3}\right)_{2}$ and $\mathrm{Co}\left(\mathrm{NO}_{3}\right)_{2} \cdot 6 \mathrm{H}_{2} \mathrm{O}$ in distilled water with a molar ratio $0.6: 0.4: 1$. Subsequently citric acid was added as complexing agent. The infiltration cycle consisted in the deposition of a droplet of LSC solution $(10 \mu 1)$ onto the LSCF electrode, followed by the calcination of the nitrates at $450^{\circ} \mathrm{C}$ for $20 \mathrm{~min}$. This cycle was repeated 4 times to reach the desired LSC/LSCF weight ratio $\sim 30-35 \mathrm{wt} \% .{ }^{47}$ One infiltration cycle with a $0.05 \mathrm{M}$ solution gives approximately $\sim 7-8 \mathrm{wt} \%$ of infiltrated LSC. The final calcination was performed at $900^{\circ} \mathrm{C}$ for $4 \mathrm{~h}$ to form the LSC perovskite phase. Later on, the cells were also prepared in the same way with $\mathrm{La}_{0.8} \mathrm{Sr}_{0.2} \mathrm{MnO}_{3}$ (LSM) infiltration in LSCF electrode to compare the effect of infiltration of different catalyst.

Electrochemical characterizations.-Symmetrical half-cells.The electrochemical properties of symmetrical half-cells were characterized by Electrochemical Impedance Spectroscopy (EIS) using a three electrodes arrangement. A platinum point placed at the edge of the electrolyte was used as reference electrode. The EIS measurements were carried out in a $700-900^{\circ} \mathrm{C}$ temperature range under zero $\mathrm{dc}$ conditions and under polarization. Platinum grids (1024 mesh) were used as current collectors.

The degradation experiments were carried out at $800^{\circ} \mathrm{C}$ up to 408 $\mathrm{h}$ under polarizations. The symmetrical half-cell was polarized using an initial voltage of $V=+25 \mathrm{mV}$ for $24 \mathrm{~h}$ applied on the working electrode (WE) (upper electrode) for electrolysis mode (anodic polarization). In this manner the counter electrode (CE) (lower electrode) operates in fuel cell mode (cathodic polarization). The voltage was increased gradually by $25 \mathrm{mV}$ each day till $400 \mathrm{mV}$.

The impedance diagrams were recorded after each $24 \mathrm{~h}$ at $i_{\mathrm{dc}}=0$ condition, at steady state under potentiostatic control with $50 \mathrm{mV} a c$ amplitude, from $10^{6} \mathrm{~Hz}$ down to $10^{-1} \mathrm{~Hz}$, using an IVIUM VERTEX potentiostat/galvanostat with integrated frequency response analyzer module. The complex impedance diagrams were analyzed by means of the Zview (Scribner Associates) software. The polarization resistance $\left(R_{\mathrm{p}}\right)$ values were calculated from the difference between the low (LF) and the high frequencies (HF) diagram intercepts with the real axis of the Nyquist representation.

Single cells. $-i$ - $V$ curves and impedance diagrams were investigated in the $700-900^{\circ} \mathrm{C}$ temperature range. In this case, platinum and nickel grids (1024 mesh) were used as current collectors for oxygen electrode and fuel electrode respectively. The $i$ - $V$ characteristic was measured from fuel cell mode $(0.6 \mathrm{~V})$ to electrolysis mode $(1.5 \mathrm{~V})$ 

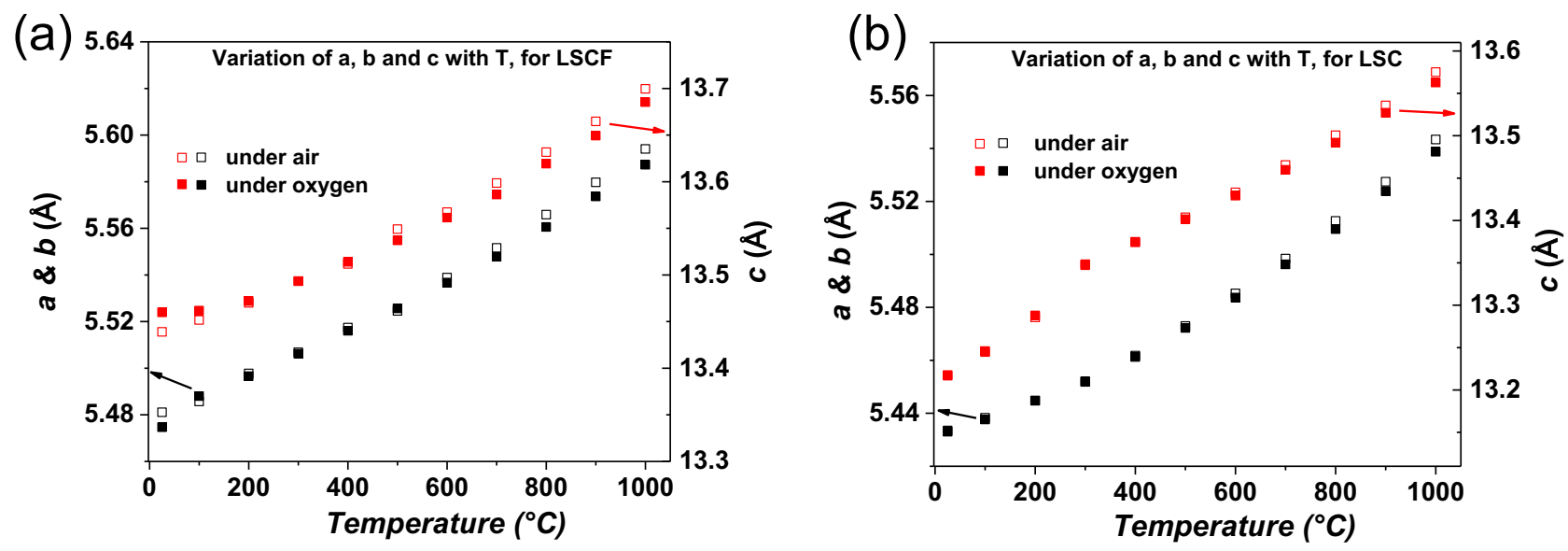

Figure 1. Variation of lattice parameters of (a) LSCF and (b) LSC as a function of temperature.

with $50 \% \mathrm{H}_{2} \mathrm{O}$ and $50 \% \mathrm{H}_{2}$ mixture. The impedance diagrams were recorded at $0.7, \mathrm{OCV}, 1.0,1.1,1.2,1.3,1.4$ and $1.5 \mathrm{~V}$.

SEM analyses.-The microstructures of electrodes and the posttest analysis of cells were investigated by field emission Scanning Electron Microscopy, Quanta FEG 650 (FEI) equipped with an EDS detector.

\section{Results and Discussion}

The XRD characterization of as-prepared LSCF and LSC phases show that these materials crystalize in a rhombohedral structure with $R-3 c$ space group. The full pattern profile matching refinements leads to determine the following lattice parameters $\mathrm{a}=\mathrm{b}=5.4810(4) \AA$, $\mathrm{c}=13.439(3) \AA$ and $\mathrm{a}=\mathrm{b}=5.4335(4) \AA, \mathrm{c}=13.217(3) \AA$ for LSCF and LSC respectively. These values are in good agreement with the previously reported results. ${ }^{57,58}$

Thermal behavior of the materials with temperature under air and oxygen (XRD vs. T).-The thermal variation of the X-ray patterns under air shows that both LSCF and LSC phases remain stable up to $1000^{\circ} \mathrm{C}$; with increasing temperature, the structure always keeps the rhombohedral symmetry and is still indexed with the $R-3 c$ space group. The Fullprof refinements were carried for all XRD pattern to investigate the lattice constants. The absence of additional peaks with regard to the room temperature diagram confirms the stability of both materials up to $1000^{\circ} \mathrm{C}$ under air and oxygen. In Figures $1 \mathrm{a}, 1 \mathrm{~b}$, the variations of $\mathrm{a}, \mathrm{b}$ and $\mathrm{c}$ lattice parameters as a function of temperature are plotted for LSCF and LSC, respectively. All of them show almost linear increase throughout the temperature range, at least for $\mathrm{T}>200^{\circ} \mathrm{C}$.

The thermal expansion coefficients of LSCF and LSC were calculated from the thermal variation of lattice parameters i.e. the slope of $\left(\mathrm{L}-\mathrm{L}_{\mathrm{o}}\right) / \mathrm{L}_{\mathrm{o}}$ vs. $\mathrm{T}$ as shown in Figures $2 \mathrm{a}, 2 \mathrm{~b}$, where $\mathrm{L}$ and $\mathrm{L}_{\mathrm{o}}$ are the cubic root of the volume at a particular and room temperatures, respectively. The values of the TEC are $17 \times 10^{-6 \circ} \mathrm{C}^{-1}$ and $16 \times$ $10^{-1}{ }^{\circ} \mathrm{C}^{-1}$ under air and oxygen respectively for LSCF. The values of TEC are $23 \times 10^{-6 \circ} \mathrm{C}^{-1}$ and $22 \times 10^{-6 \circ} \mathrm{C}^{-1}$ under air and oxygen respectively for LSC. A slight decrease in the TEC is then observed for both LSCF and LSC material under oxygen compare to air. The values of the TEC of LSCF and LSC under air are in good agreement with the previous reported results. ${ }^{57,59,60}$

Phase, microstructure and electrochemical characterization of LSC infiltrated LSCF symmetrical cell.-To investigate the phase formation of LSC, the precursor's solution (as described in the experimental part) of LSC was first dried and decarbonized at $200^{\circ} \mathrm{C}$ and then calcined at $900^{\circ} \mathrm{C}$ for $4 \mathrm{~h}$ under air, the resulting powder was characterized by X-ray diffraction. Figure 3 shows the $\mathrm{X}$-ray diffraction patterns of the LSC powder obtained after calcination. XRD of the powder prepared from the precursor's solution confirms the LSC phase formation without the presence of any impurity. The LSC phase formation test was not performed with the infiltrated electrode as the

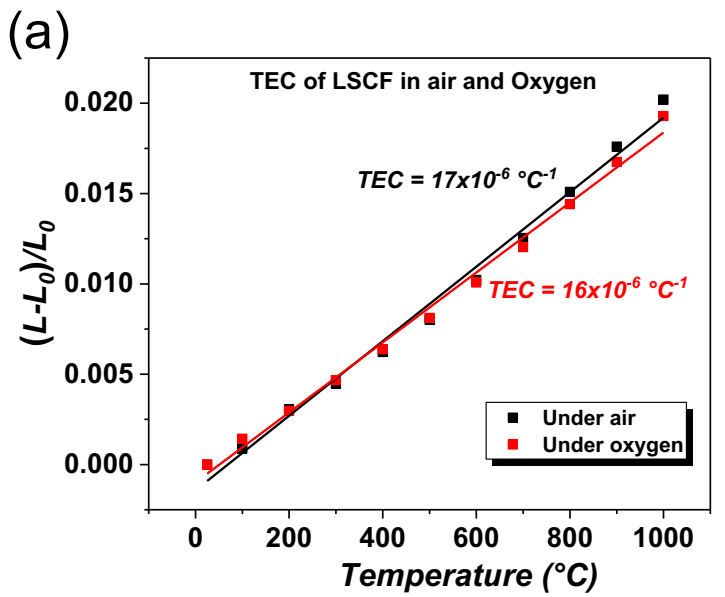

(b)

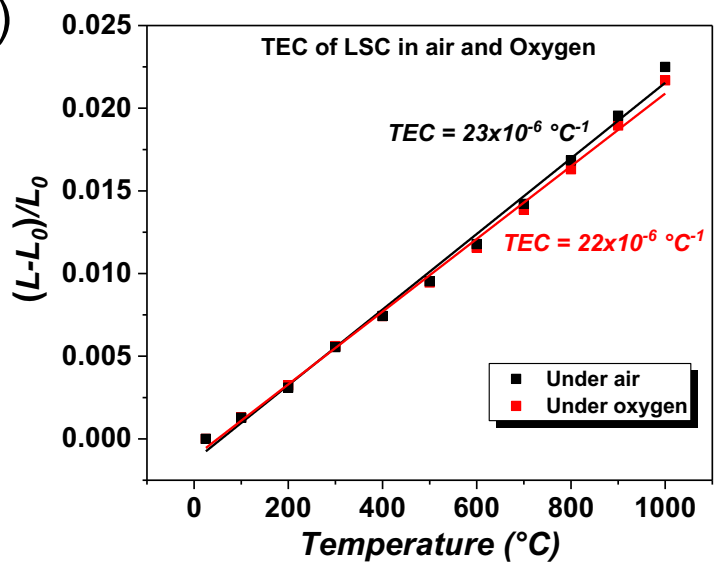

Figure 2. Variation of TECs of (a) LSCF and (b) LSC as a function of temperature. 


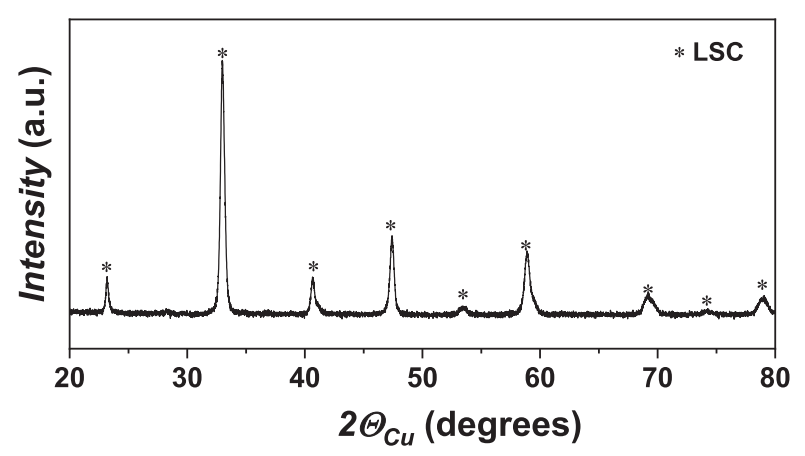

Figure 3. XRD pattern of LSC phase formation after calcination at $900^{\circ} \mathrm{C}$ for $4 \mathrm{~h}$.

peak positions of LSC and LSCF are very close and hence difficult to distinguish.

Figures $4 \mathrm{a}, 4 \mathrm{~b}$ shows SEM pictures of a fractured cross-section after a heat-treatment at $900^{\circ} \mathrm{C}$ for $4 \mathrm{~h}$ of conventional LSCF and LSC infiltrated symmetrical cells respectively. The conventional LSCF electrode shows the larger interconnected grains. For the infiltrated sample, the LSCF grains are covered with a partly interconnected network of small grains. It is clear that the infiltrated phase entirely covers the LSCF grains and annealing treatment sintered the infiltrated phase to the surface of the LSCF grains. The infiltrated LSC nanoparticles with particle size less than $50 \mathrm{~nm}$ are uniformly distributed on the LSCF scaffold with 30-35 wt\% of LSC mass loading (Figure 4b). As a result the surface area is greatly enhanced for the oxygen electrode reaction process, which may enhance the overall performance of oxygen electrode.

Polarization resistance measurements under air, $i_{d c}=0 .-$ The symmetrical cell was mounted into the measurement setup, with flow of air. The cell was heated at $900^{\circ} \mathrm{C}$ and the impedance diagrams were investigated by EIS at $i_{d c}=0$ condition.

The electrochemical behavior of symmetrical cells containing LSCF electrode with and without infiltration were recorded in the $700-900^{\circ} \mathrm{C}$ temperature range. The variation of impedance spectra of symmetrical half-cells at $800^{\circ} \mathrm{C}$ is shown in Fig. 5a, as an example. The impedance spectra of all samples consist of two distinguished arcs and can be fitted using three time constants (R//CPE) in addition to an ohmic resistance $\left(R_{\mathrm{S}}\right)$ and an instrument induced inductivity $(L)$ (Figure 5a) and the fitting parameters are given in the supporting information Table S1. In the current study the fit was limited to the extraction of the polarization resistance $\left(R_{p}\right)$ value, therefore no attempt was made to interpret the three elements representing the total electrode processes. However, in general, these three electrode processes could be linked with charge transfer process at electrode/ electrolyte interface, adsorption/desorption and oxide ion diffusion inside the porous electrode and molecular oxygen gas diffusion process. ${ }^{61}$

Figure $5 \mathrm{~b}$ shows the variation of $R_{\mathrm{p}}$ with temperature for the LSCF electrode with and without infiltration. An improvement in the $R_{\mathrm{p}}$ value is observed with LSC infiltration. For instance, the $R_{\mathrm{p}}$ values at $800^{\circ} \mathrm{C}$ are 38 and $22 \mathrm{~m} \Omega . \mathrm{cm}^{2}$ for conventional LSCF and LSM

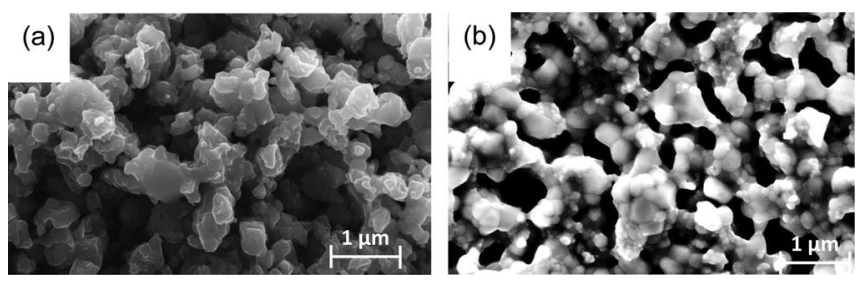

Figure 4. Fractured cross-section of the symmetrical half-cell with, a) conventional LSCF electrode and b) LSC infiltrated LSCF electrode.
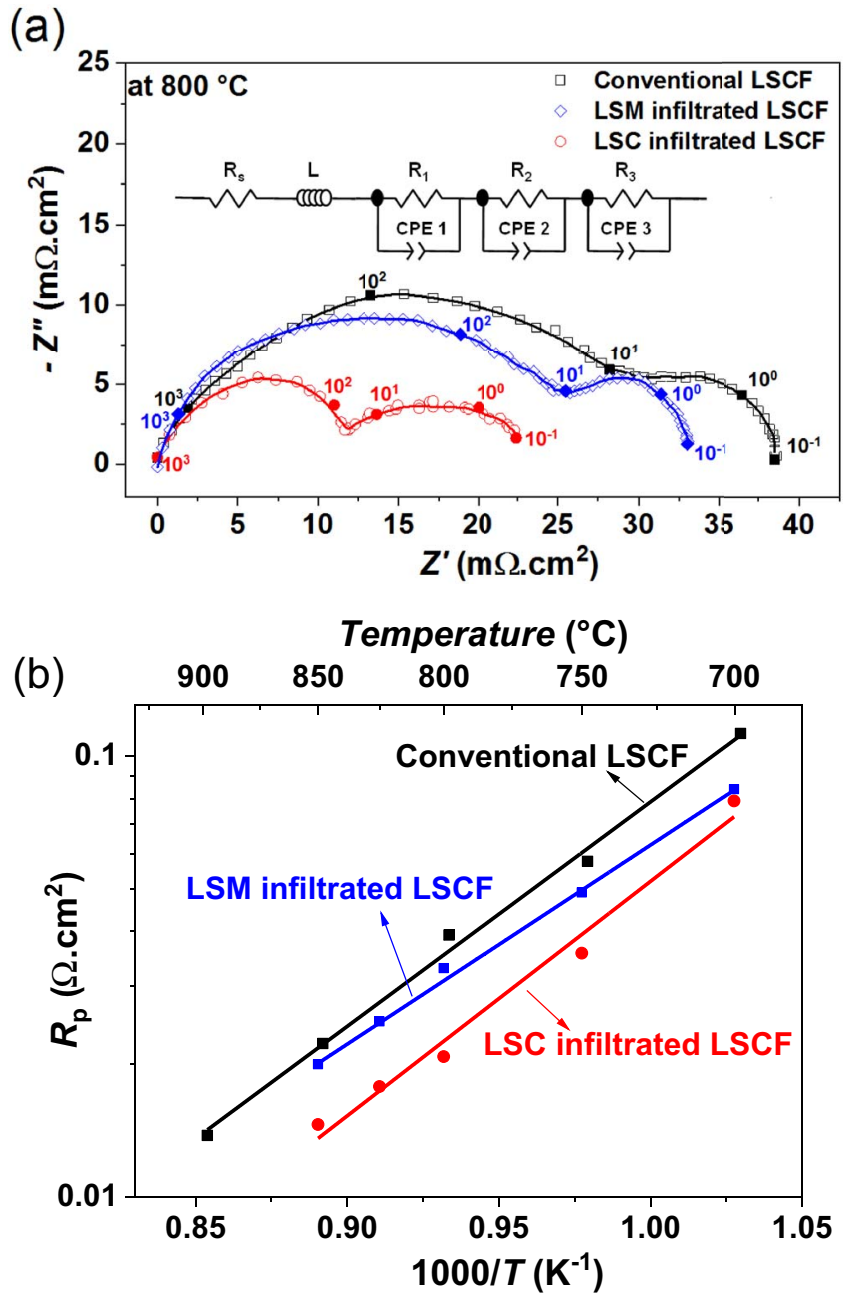

Figure 5. (a) Impedance spectra (plotted in Nyquist form) recorded at $800^{\circ} \mathrm{C}$ under OCV conditions and (b) Arrhenius plots of $R_{\mathrm{p}}$, for conventional LSCF electrode, LSC infiltrated LSCF electrode and LSM infiltrated LSCF electrode.

infiltrated LSCF electrodes, respectively. The activation energies for LSCF electrode with and without infiltration are $118 \pm 0.07 \mathrm{~kJ} . \mathrm{mol}^{-1}$ and $129 \pm 0.05 \mathrm{~kJ} \mathrm{~mol}^{-1}$, respectively. Importantly, the activation energies of the calculated $R_{\mathrm{p}}$ values show similar values. The activation energy of the conventional LSCF electrode matches earlier reported literature value ${ }^{62-64}$ On the other hand, LSM infiltrated LSCF cell shows slight improvement in the electrochemical performance compared to LSC infiltration under same preparation and measurements conditions. The $R_{\mathrm{p}}$ values at $800^{\circ} \mathrm{C}$ are 38 and $33 \mathrm{~m} \Omega . \mathrm{cm}^{2}$ for conventional LSCF and LSM infiltrated LSCF electrodes, respectively. It is clearly evident that the polarization resistance is improved throughout the whole temperature range for both LSC and LSM infiltrated sample but the best performance is obtained for LSC infiltrated LSCF cell, therefore we considered LSC infiltrated LSCF cell to perform the long term degradation test. Zhu et al. have also reported the effect of LSM infiltration in the LSCF oxygen electrode and found the improvement in the performance under SOFC operation. ${ }^{65}$

Electrode degradation studies with symmetrical cells under polarization.-Degradation studies of symmetrical cells containing conventional LSCF and LSC infiltrated LSCF electrode were performed under polarization at $800^{\circ} \mathrm{C}$, starting from $25 \mathrm{mV}$ up to $400 \mathrm{mV}$ with an increment of $25 \mathrm{mV}$ each day. The impedance spectra were recorded at $i_{\mathrm{dc}}=0$ after each $24 \mathrm{~h}$ up to $408 \mathrm{~h}$. The obtained $R_{\mathrm{p}}$ values are plotted as a function of time in Figure 6. 


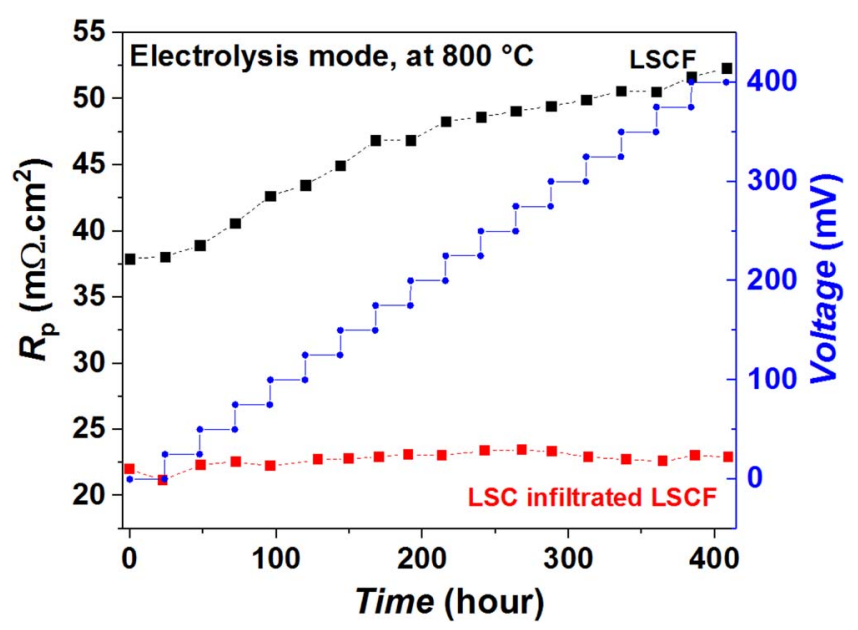

Figure 6. Degradation experiment with symmetrical cells containing conventional LSCF and LSC infiltrated LSCF electrode under electrolysis mode.

In electrolysis mode (i.e. under anodic polarization), an increase in $R_{\mathrm{p}}$ values is noticed with increasing time and voltage for conventional LSCF symmetrical cell. The $R_{\mathrm{p}}$ value at $\mathrm{t}=0$ is $\sim 38 \mathrm{~m} \Omega . \mathrm{cm}^{2}$ which increases with time and reaches $\sim 52 \mathrm{~m} \Omega . \mathrm{cm}^{2}$ after $408 \mathrm{~h}$, i.e. showing $\sim 37 \%$ overall degradation. The variation of impedance spectra with time shows that there is a continuous increase in ohmic resistance $\left(R_{\mathrm{s}}\right)$ in addition to $R_{\mathrm{p}}$, as shown in the supporting information Figure $\mathrm{S} 1(\mathrm{a})$. The ohmic resistances were calculated from these spectra and depicted their vitiation with time in Figure S2. A continuous increase in observed throughout the experiment like the $R_{\mathrm{p}}$ of the LSCF cell.

For LSC infiltrated LSCF symmetrical half-cell, on the other hand, almost no degradation (constant $R_{\mathrm{p}}$ ) is observed in electrolysis mode under same conditions, as shown in Figure 6. Moreover the $R_{\mathrm{s}}$ seems also stable throughout the measurement (Figure S1 (b) and S2). To understand the reason for such degradation post-mortem analysis were performed after degradation test.

Post-test analyses of symmetrical cells.-SEM analyses.-The symmetrical cells were inspected using SEM after electrochemical measurement. There are mainly four regions for characterizing the cross section i.e. electrolyte, electrodes, electrode/GDC interface and GDC/electrolyte interface. As there is almost no change observed in the bulk of the electrodes and the electrolyte, the electrode/GDC and GDC/electrolyte interfaces are mainly discussed here. Figure 7 compares the electrode//GDC//electrolyte interfaces after operation under anodic polarization, for LSCF and LSC infiltrated LSCF symmetrical cells. The electrode/GDC layer is partly delaminated from the electrolyte for conventional LSCF symmetrical cell. Remarkably no such delamination was observed after operation in cathodic polarization (not reported).

A detailed analysis of these interfaces after operation under anodic polarization reveals that the partial delamination is present at the electrode/GDC as well as the GDC/electrolyte interface after $408 \mathrm{~h}$ of operation, as shown in Figure 7a. It can be expected that the de-
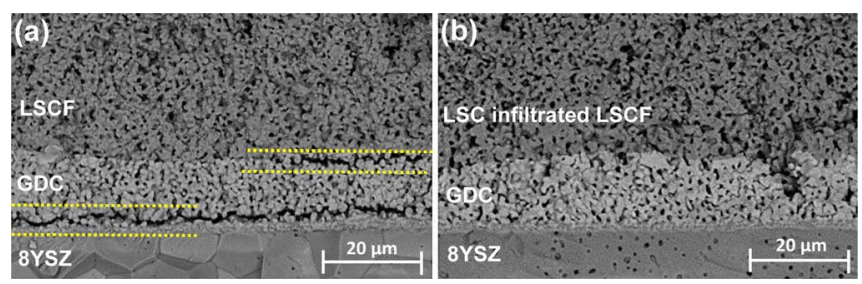

Figure 7. (a) Conventional LSCF and (b) LSC infiltrated LSCF symmetrical half-cell after degradation experiment at $800^{\circ} \mathrm{C}$ up to $408 \mathrm{~h}$ under anodic polarization.

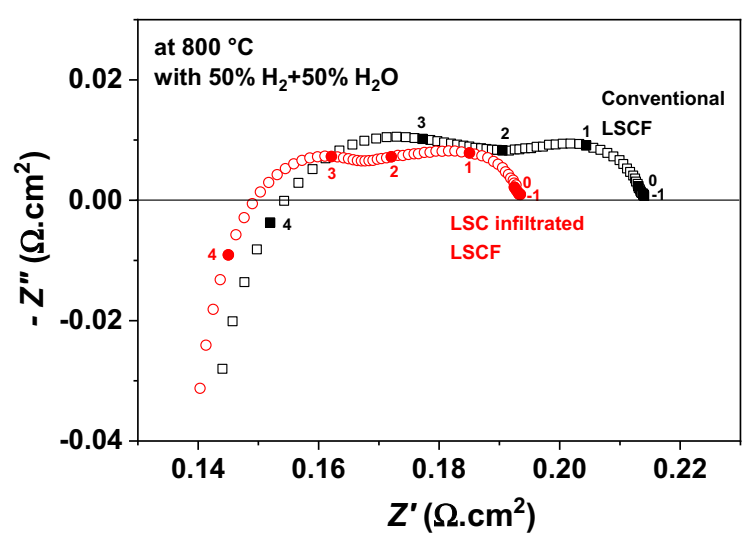

Figure 8. Nyquist plot at $\mathrm{OCV}$ at $800^{\circ} \mathrm{C}$ for single cell containing $\mathrm{LSCF}$ and LSC infiltrated LSCF oxygen electrode with $50 \% \mathrm{H}_{2}+50 \% \mathrm{H}_{2} \mathrm{O}$.

lamination could be even more severe if the cell is operated longer. Indeed Mawdsley et al. have reported the partial delamination of oxygen electrode in the stack test after $1000 \mathrm{~h}$ of operation, which became more severe after $2000 \mathrm{~h}$ of operation, causes largest contribution to the stack performance degradation under electrolysis conditions. ${ }^{34}$

The delamination could be linked with the high partial pressure of oxygen at both interfaces (electrode/GDC as well as the GDC/electrolyte). ${ }^{33,34}$ Another possible reason for the delamination of GDC from the electrolyte could be the SrO mobility. In our case, the GDC layer is not completely dense which means that it cannot stop the migration of volatile $\mathrm{SrO}$ to electrolyte through the GDC layer. Subsequently the $\mathrm{SrO}$ reacts with zirconia to form a $\mathrm{SrZrO}_{3}$ insulating phase. An EDX analysis at the GDC/electrolyte interface confirms the presence of $\mathrm{Sr}$ at the GDC/electrolyte interface, as shown in Figure S3. Despite the stability of the electrode materials at high temperature (XRD vs. T) the formation of SrO takes place during long term and/or under operating conditions.

On the other hand, for LSC infiltrated LSCF symmetrical cell, no delamination of electrode and/or electrode-GDC interface is observed at the interfaces under anodic polarization, as shown in Figure 7b. This could be due to enhancement of the electrode surface area, increase in the catalytic activity of the infiltrated electrode, easier transport of the oxide ions at the electrode/electrolyte interface as well as the modification of the electrode microstructure. In addition, the infiltrated LSC particles can effectively shift the active reaction sites from electrode/electrolyte interface to the surface of LSCF scaffold, this also might be the additional reason to avoid delamination and significantly enhance the structural stability of oxygen electrode. However, the presence of $\mathrm{Sr}$ is also observed at GDC/YSZ interface for LSC infiltrated LSCF cell but the extent is much lower compared to LSCF cell (Figure S3), clearly indicating that the infiltration of LSC suppresses the Sr-segregation.

Single cell measurements.-The single cell was mounted into the measurement setup, with flows of air and $\mathrm{N}_{2}$ on the anode and cathode sides, respectively. The cell was heated at $900^{\circ} \mathrm{C}$ and $\mathrm{N}_{2}$ at the cathode side was progressively replaced by dry hydrogen $\left(\mathrm{H}_{2}\right)$ to reduce $\mathrm{NiO}$ into metallic Ni. Then the temperature was decreased to $800^{\circ} \mathrm{C}$ for the electrochemical measurements. The open circuit voltage (OCV) was around $1.15 \mathrm{~V}$ at dry conditions.

Figure 8 shows the Nyquist plots recorded for single cells with LSC infiltrated LSCF and a conventional LSCF electrode, in both cases with $50 \% \mathrm{H}_{2}$ and $50 \% \mathrm{H}_{2} \mathrm{O}$ at $800^{\circ} \mathrm{C}$ under $\mathrm{OCV}$ condition. The two cells have almost identical series resistance but the cell with LSC infiltration shows lower $R_{\mathrm{p}}$. The $R_{\mathrm{p}}$ value of 80 and $60 \mathrm{~m} \Omega . \mathrm{cm}^{2}$ are obtained for conventional LSCF and LSC infiltrated LSCF electrode containing single cells, respectively at $800^{\circ} \mathrm{C}$ under $\mathrm{OCV}$ condition. As expected, the $R_{\mathrm{p}}$ values measured on single cells are higher than that of symmetrical cell $\left(38 \mathrm{~m} \Omega . \mathrm{cm}^{2}\right.$ and $22 \mathrm{~m} \Omega . \mathrm{cm}^{2}$ for conventional 


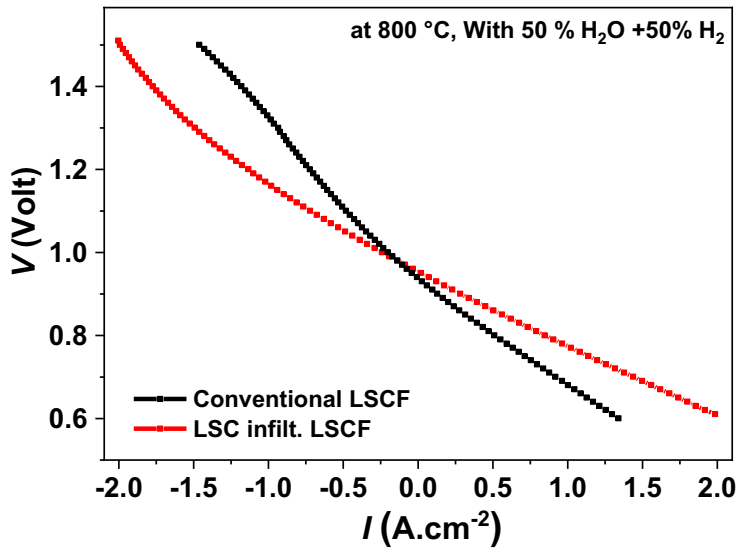

Figure 9. Current density-voltage relationship curves, at $800^{\circ} \mathrm{C}$ for single cell containing LSCF and LSC infiltrated LSCF oxygen electrode with $50 \% \mathrm{H}_{2}+$ $50 \% \mathrm{H}_{2} \mathrm{O}$.

LSCF and LSC infiltrated LSCF electrode containing symmetrical cells), as the contribution of cathode i.e. the fuel electrode is also appearing in single cell.

Figure 9 shows the $i$ - $V$ relationship at $800^{\circ} \mathrm{C}$ for cells with both the conventional LSCF and LSC infiltrated LSCF electrode. The maximum current density reaches approximately 1.4 and $2 \mathrm{~A} \cdot \mathrm{cm}^{-2}$ for conventional LSCF and LSC infiltrated LSCF single cell, respectively, under fuel cell mode. In electrolysis mode, the maximum current density reaches nearly -1.5 and $-2 \mathrm{~A} \cdot \mathrm{cm}^{-2}$ for conventional and infiltrated single cell respectively. It is seen that the single cell with LSC infiltrated LSCF electrode performs better than the conventional LSCF electrode in both SOFC and SOEC modes.

To further reveal the hydrogen production performance of the cells, the hydrogen production rate in SOEC mode can be directly calculated from the measured current using following equation:

$$
N_{H_{2}}=-I / 2 F
$$

Where $N_{H_{2}}$ is the molar rate of hydrogen production $\left(\mathrm{mol} \cdot \mathrm{cm}^{-2} \cdot \mathrm{s}^{-1}\right)$, I is the current density and $\mathrm{F}$ is Faraday's constant. For more clarity the unit of hydrogen production rate is further converted into $\mathrm{ml} \cdot \mathrm{cm}^{-2} \cdot \mathrm{h}^{-1}$.

At $800^{\circ} \mathrm{C}$, the calculated hydrogen production rate can be up to $627 \mathrm{ml} \cdot \mathrm{cm}^{-2} \cdot \mathrm{h}^{-1}$ at $1.5 \mathrm{~V}$ with $50 \% \mathrm{H}_{2}$ and $50 \% \mathrm{H}_{2} \mathrm{O}$ for the LSCF containing single cell whereas for LSC infiltrated cell it is $835 \mathrm{ml} \cdot \mathrm{cm}^{-2} \cdot \mathrm{h}^{-1}$ under same conditions, which is much higher than that of recently reported LSCN infiltrated GDC cells $\left(543 \mathrm{ml} \cdot \mathrm{cm}^{-2} \cdot \mathrm{h}^{-1}\right){ }^{66}$ Other reported values in the literature for the single cells are for ex. LSCF-GDC//GDC//8YSZ//NiOYSZ $\left(250 \mathrm{ml} \cdot \mathrm{cm}^{-2} \cdot \mathrm{h}^{-1}\right.$ at $\left.750^{\circ} \mathrm{C}^{67}\right), \mathrm{Nd}_{2} \mathrm{NiO}_{4+\delta} / / \mathrm{TZ} 3 \mathrm{Y} / / \mathrm{NiO}-$ GDC $\left(376 \mathrm{ml} \cdot \mathrm{cm}^{-2} \cdot \mathrm{h}^{-1}\right.$ at $\left.800^{\circ} \mathrm{C}\right),{ }^{26} \mathrm{BSCF} / / 8 \mathrm{YSZ} / / \mathrm{NiO}-\mathrm{YSZ}$ cell $\left(200 \mathrm{ml} \cdot \mathrm{cm}^{-2} \cdot \mathrm{h}^{-1}\right.$ at $\left.850^{\circ} \mathrm{C}\right),{ }^{68} \mathrm{SSC}-\mathrm{SDC} 73 / / 8 \mathrm{YSZ} / \mathrm{NiO}-\mathrm{YSZ}(327$ $\mathrm{ml} \cdot \mathrm{cm}^{-2} \cdot \mathrm{h}^{-1}$ at $\left.850^{\circ} \mathrm{C}\right){ }^{69}$ These results indicate that LSC infiltrated LSCF electrode can be very promising oxygen electrode for high temperature electrolysis applications. The long term electrolysis experiments with the single cells are currently under progress and will be reported in a forthcoming paper.

\section{Conclusions}

This work reports the results on the study of LSC infiltrated LSCF oxygen electrode and comparison with conventional screen-printed LSCF oxygen electrode under electrolysis conditions (anodic polarization). Chemical and structural stability of both LSCF and LSC phases were first investigated as a function of temperature (XRD vs. $\mathrm{T})$, revealing that these phases are very stable under air and oxygen, as no peaks of impurities such as $\mathrm{SrO}$ is detected.
The polarization resistance $\left(R_{\mathrm{p}}\right)$ values obtained for "8YSZ//GDC//LSCF" symmetrical half-cells with and without infiltration are $22 \mathrm{~m} \Omega . \mathrm{cm}^{2}$ and $38 \mathrm{~m} \Omega . \mathrm{cm}^{2}$ respectively, at $800^{\circ} \mathrm{C}$ under $i_{\mathrm{dc}}=0$ condition. An improvement in the $R_{\mathrm{p}}$ value is observed for LSC infiltrated sample throughout the temperature range of $700-900^{\circ} \mathrm{C}$. A degradation experiment was performed with the symmetrical cells till up to $408 \mathrm{~h}$ with an increase of potential 25 $\mathrm{mV}$ each day. The overall degradation rate of $\sim 37 \%$ and $\sim 0 \%$ are observed for conventional LSCF and LSC infiltrated LSCF symmetrical cell respectively after $408 \mathrm{~h}$ under anodic polarization. The post-mortem analysis of these symmetrical cells containing LSCF electrode reveals that the partial delamination of oxygen electrode occurs under anodic polarization, leading to an increase in $R_{\mathrm{p}}$ values. Interestingly, no delamination is observed with LSC infiltrated symmetrical half-cell under the same condition.

The behavior of Ni-YSZ supported single cells "NiYSZ//8YSZ//GDC//oxygen electrode is investigated in the 700 $900{ }^{\circ} \mathrm{C}$ temperature range with $50 \% \mathrm{H}_{2}$ and $50 \% \mathrm{H}_{2} \mathrm{O}$. An improvement in the performance is obtained with LSC infiltration. A maximum current density value of -1.5 and $-2 \mathrm{~A} . \mathrm{cm}^{-2}$ is obtained for conventional LSCF and LSC infiltrated LSCF single cell at $800^{\circ} \mathrm{C}$ under an applied electrolysis voltage of $1.5 \mathrm{~V}$. The hydrogen production rate is 627 and $835 \mathrm{ml} \cdot \mathrm{cm}^{-2} \cdot \mathrm{h}^{-1}$ at $800^{\circ} \mathrm{C}$ for LSCF and LSC infiltrated LSCF cells.

Finally, it can be concluded that the infiltration of LSC in a LSCF scaffold significantly improves the electrochemical performance of oxygen electrode and enhance the hydrogen production rate under high temperature electrolysis conditions. The long term electrolysis experiments with the single cells are currently under progress and will be reported in the forthcoming paper.

\section{Acknowledgments}

The results reported here were obtained within the frame of an European project SElySOs. This project has received funding from the Fuel Cells and Hydrogen Joint Undertaking under grant agreement No 671481. This Joint Undertaking receives support from the European Union's Horizon 2020 research and innovation programme and Greece, Germany, Czech Republic, France, Norway.

\section{ORCID}

\section{Vibhu (D https://orcid.org/0000-0001-9157-2722}

\section{References}

1. S. H. Jensen, P. H. Larsen, and M. Mogensen, International Journal of Hydrogen Energy, 32, 3253 (2007)

2. J. Udagawa, P. Aguiar, and N. P. Brandon, Journal of Power Sources, 166, 127 (2007)

3. A. Hauch, S. D. Ebbesen, S. H. Jensen, and M. Mogensen, Journal of Materials Chemistry, 18, 2331 (2008)

4. S. D. Ebbesen, S. H. Jensen, A. Hauch, and M. B. Mogensen, Chemical Reviews, 114, 10697 (2014)

5. C. Graves, S. D. Ebbesen, M. Mogensen, and K. S. Lackner, Renewable and Sustainable Energy Reviews, 15, 1 (2011).

6. S. D. Ebbesen, C. Graves, and M. Mogensen, International Journal of Green Energy, 6, 646 (2009).

7. S. R. Foit, I. C. Vinke, L. G. J. de Haart, and R.-A. Eichel, Angewandte Chemie International Edition, 56, 5402 (2017).

8. V. I. Sharma and B. Yildiz, Journal of The Electrochemical Society, 157, B441 (2010)

9. K. Chen and S. P. Jiang, Journal of The Electrochemical Society, 163, F3070 (2016).

10. C. Graves, S. D. Ebbesen, S. H. Jensen, S. B. Simonsen, and M. B. Mogensen, Nat Mater, 14, 239 (2015).

11. S. D. Ebbesen, X. Sun, and M. B. Mogensen, Faraday Discussions, 182, 393 (2015)

12. J. Park, D. Kim, J. Baek, Y.-J. Yoon, P.-C. Su, and S. Lee, Energies, 11, 1204 (2018)

13. O. Yamamoto, Y. Takeda, R. Kanno, and M. Noda, Solid State Ionics, 22, 241 (1987).

14. O. Yamamoto, Electrochimica Acta, 45, 2423 (2000).

15. Y. Patcharavorachot, A. Arpornwichanop, and A. Chuachuensuk, Journal of Power Sources, 177, 254 (2008)

16. P. Hjalmarsson, M. Søgaard, and M. Mogensen, Solid State Ionics, 179, 1422 (2008).

17. A. Samson, M. Søgaard, R. Knibbe, and N. Bonanos, Journal of The Electrochemical Society, 158, B650 (2011)

18. J.-M. Bassat, V. Vibhu, C. Nicollet, A. Flura, S. Fourcade, J.-C. Grenier, and A. Rougier, ECS Transactions, 78, 655 (2017). 
19. V. Vibhu, J.-M. Bassat, A. Flura, C. Nicollet, J.-C. Grenier, and A. Rougier, ECS Transactions, 68, 825 (2015).

20. V. Vibhu, A. Flura, C. Nicollet, S. Fourcade, N. Penin, J.-M. Bassat, J.-C. Grenier, A. Rougier, and M. Pouchard, Solid State Sciences, 81, 26 (2018).

21. V. Vibhu, A. Rougier, C. Nicollet, A. Flura, J.-C. Grenier, and J.-M. Bassat, Solid State Ionics, 278, 32 (2015).

22. S. Choi, S. Yoo, J. Kim, S. Park, A. Jun, S. Sengodan, J. Kim, J. Shin, H. Y. Jeong, Y. Choi, G. Kim, and M. Liu, 3, 2426 (2013).

23. Q. Liu, C. Yang, X. Dong, and F. Chen, International Journal of Hydrogen Energy, 35, 10039 (2010).

24. Y. Liu, Y. Cao, S. Yang, D. Yan, B. Chi, J. Pu, and L. Jian, Fuel Processing Technology, 135, 203 (2015).

25. K. Zhang, L. Ge, R. Ran, Z. Shao, and S. Liu, Acta Materialia, 56, 4876 (2008).

26. F. Chauveau, J. Mougin, J. M. Bassat, F. Mauvy, and J. C. Grenier, Journal of Power Sources, 195, 744 (2010).

27. C. Ferchaud, J.-C. Grenier, Y. Zhang-Steenwinkel, M. M. A. van Tuel, F. P. F. van Berkel, and J.-M. Bassat, Journal of Power Sources, 196, 1872 (2011)

28. V. Vibhu, A. Rougier, C. Nicollet, A. Flura, S. Fourcade, N. Penin, J.-C. Grenier, and J.-M. Bassat, Journal of Power Sources, 317, 184 (2016).

29. E. V. Tsipis and V. V. Kharton, Journal of Solid State Electrochemistry, 12, 1367 (2008).

30. Y. Li, R. Gemmen, and X. Liu, Journal of Power Sources, 195, 3345 (2010).

31. L. C. Baqué, A. L. Soldati, E. Teixeira-Neto, H. E. Troiani, A. Schreiber, and A. C. Serquis, Journal of Power Sources, 337, 166 (2017).

32. J. Druce, T. Ishihara, and J. Kilner, Solid State Ionics, 262, 893 (2014).

33. A. V. Virkar, International Journal of Hydrogen Energy, 35, 9527 (2010).

34. J. R. Mawdsley, J. David Carter, A. Jeremy Kropf, B. Yildiz, and V. A. Maroni, International Journal of Hydrogen Energy, 34, 4198 (2009).

35. D. Oh, D. Gostovic, and E. D. Wachsman, Journal of Materials Research, 27, 1992 (2012).

36. L. Zhao, J. Drennan, C. Kong, S. Amarasinghe, and S. P. Jiang, Journal of Materials Chemistry A, 2, 11114 (2014).

37. E. Bucher, W. Sitte, F. Klauser, and E. Bertel, Solid State Ionics, 191, 61 (2011).

38. S. J. Kim and G. M. Choi, Solid State Ionics, 262, 303 (2014).

39. Z. Liu, M. Liu, L. Yang, and M. Liu, Journal of Energy Chemistry, 22, 555 (2013).

40. H. Ding, A. V. Virkar, M. Liu, and F. Liu, Physical Chemistry Chemical Physics, 15, 489 (2013).

41. Y. Chen, Y. Chen, D. Ding, Y. Ding, Y. Choi, L. Zhang, S. Yoo, D. Chen, B. deGlee, H. Xu, Q. Lu, B. Zhao, G. Vardar, J. Wang, H. Bluhm, E. J. Crumlin, C. Yang, J. Liu, B. Yildiz, and M. Liu, Energy \& Environmental Science, 10, 964 (2017).

42. C. Nicollet, A. Flura, V. Vibhu, S. Fourcade, A. Rougier, J.-M. Bassat, and J.-C. Grenier, Journal of Solid State Electrochemistry, 20, 2071 (2016).

43. C. Nicollet, A. Flura, V. Vibhu, A. Rougier, J.-M. Bassat, and J.-C. Grenier, International Journal of Hydrogen Energy.
44. A. Chrzan, J. Karczewski, M. Gazda, D. Szymczewska, and P. Jasinski, Journal of the European Ceramic Society, 37, 3559 (2017).

45. A. Chrzan, S. Ovtar, P. Jasinski, M. Chen, and A. Hauch, Journal of Power Sources, 353, 67 (2017).

46. D. Ding, X. Li, S. Y. Lai, K. Gerdes, and M. Liu, Energy \& Environmental Science, 7, 552 (2014).

47. C. Nicollet, A. Flura, V. Vibhu, A. Rougier, J. M. Bassat, and J. C. Grenier, Journal of Power Sources, 294, 473 (2015).

48. J. M. Vohs and R. J. Gorte, Advanced Materials, 21, 943 (2009).

49. A. J. Samson, M. Søgaard, and N. Bonanos, Electrochemical and Solid-State Letters, 15, B54 (2012).

50. D. Ding, M. Liu, Z. Liu, X. Li, K. Blinn, X. Zhu, and M. Liu, Advanced Energy Materials, 3, 1149 (2013)

51. A. Petric, P. Huang, and F. Tietz, Solid State Ionics, 135, 719 (2000).

52. S. Shinichi, Y. Masaru, H. Ken, and Y. Osamu, Journal of the American Ceramic Society, 80, 267 (1997).

53. A. Mineshige, M. Inaba, T. Yao, Z. Ogumi, K. Kikuchi, and M. Kawase, Journal of Solid State Chemistry, 121, 423 (1996).

54. M. Søgaard, P. V. Hendriksen, M. Mogensen, F. W. Poulsen, and E. Skou, Solid State Ionics, 177, 3285 (2006).

55. F. Bidrawn, G. Kim, N. Aramrueang, J. M. Vohs, and R. J. Gorte, Journal of Power Sources, 195, 720 (2010).

56. R. Küngas, F. Bidrawn, E. Mahmoud, J. M. Vohs, and R. J. Gorte, Solid State Ionics, 225, 146 (2012)

57. X. Chen and T. Grande, Chemistry of Materials, 25, 927 (2013).

58. M. Yashima and T. Kamioka, Solid State Ionics, 178, 1939 (2008).

59. L. W. Tai, M. M. Nasrallah, H. U. Anderson, D. M. Sparlin, and S. R. Sehlin, Solid State Ionics, 76, 259 (1995).

60. G. Corbel, S. Mestiri, and P. Lacorre, Solid State Sciences, 7, 1216 (2005).

61. V. C. Kournoutis, F. Tietz, and S. Bebelis, Fuel Cells, 9, 852 (2009).

62. E. Perry Murray, M. J. Sever, and S. A. Barnett, Solid State Ionics, 148, 27 (2002).

63. V. Dusastre and J. A. Kilner, Solid State Ionics, 126, 163 (1999).

64. D. Waller, J. A. Lane, J. A. Kilner, and B. C. H. Steele, Solid State Ionics, 86-88, 767 (1996).

65. X. Zhu, D. Ding, Y. Li, Z. Lü, W. Su, and L. Zhen, International Journal of Hydrogen Energy, 38, 5375 (2013).

66. Y. Tan, N. Duan, A. Wang, D. Yan, B. Chi, N. Wang, J. Pu, and J. Li, Journal of Power Sources, 305, 168 (2016).

67. M.-B. Choi, B. Singh, E. D. Wachsman, and S.-J. Song, Journal of Power Sources, 239, 361 (2013).

68. Y. Bo, Z. Wenqiang, X. Jingming, and C. Jing, International Journal of Hydrogen Energy, 33, 6873 (2008).

69. W. Jiang, Z. Lü, B. Wei, Z. H. Wang, X. B. Zhu, Y. T. Tian, X. Q. Huang, and W. H. Su, Fuel Cells, 14, 76 (2014). 